\title{
The Effect of Good Corporate Governance on ERM Implementation with Organizational Culture as a Moderating Variable
}

\author{
Farhan Ady Pratama* Yvonne Augustine \\ Trisakti University - Faculty Economic and Business Kyai Tapa No.1 Tomang, \\ Grogol petamburan, West Jakarta
}

\begin{abstract}
This study aims to empirically analyze the influence of Good Coprorate Governance (GCG) on the implementation of Enterprise Risk Management (ERM) with Organizational Culture (Culture) as a Moderating Variable. The data collection method used in this study is a questionnaire distributed to companies that issue sustainability reports in carrying out their business which includes managers, section heads, and employees. The data analysis method used is multiple regression analysis. The results of the study indicate that (1) There is a positive influence between Good Corporate Governance (GCG) on the implementation of Enterprise Risk Management (ERM). (2) there is no positive influence between Organizational Culture (Culture) on the implementation of Enterprise Risk Management (ERM). (3). Organizational Culture (Culture) strengthens the Effect of Good Corporate Governance on the implementation of ERM Enterprise Risk Management.
\end{abstract}

Keywords: Corporate culture, organizational culture, Corporate Governance, Good Corporate Governance, ERM, Enterprise Risk Management, Moderation

DOI: $10.7176 / \mathrm{JESD} / 10-7-03$

Publication date: April $30^{\text {th }} 2019$

\section{Introduction}

The issue of Corporate governance arises because of the separation between ownership and corporate control, or often known as agency problems. Agency problems in the relationship between capital owners and managers is how difficult the owners are in ensuring that the invested funds are not taken over or invested in projects that are not profitable so they do not bring returns. Corporate governance is needed to reduce agency problems between owners and managers (Hastuti, 2005). But in reality, the application of Good Corporate Governance (GCG) has not been able to solve the existing agency problems. The presence of Good Corporate Governance (GCG) is only used to raise the image of some companies by doing everything without thinking about the survival of the company. Failures in the implementation of Good Corporate Governance (GCG) have been discussed in the Sarbanes Oxley Act which further emphasizes the importance of implementing risk management within the company to prevent fraudulent financial operations. (Citrawati \& Fauzi 2013).

Companies in carrying out their activities are faced with uncertain conditions that can affect success or failure in achieving goals. The rapid development of external and internal environments leads to increasingly complex business risks (Sanjaya and Linawati, 2015). To deal with existing conditions, companies need to provide management tools that can manage risk (Widjaya and Sugiarti, 2013). Good risk management will not only increase business certainty but also increase competitive advantage and company value.

Risk management is an integral component of the company's strategy and its implementation is carried out as an action to prevent and mitigate risk to the smallest level of risk, so that the company can survive in competition. Efforts to improve the quality of implementation of risk management can be done through integrated risk management, namely risk management company implementation (ERM).

Corporate culture, meanwhile, can be defined as "a set of morals, values, attitudes, beliefs and meanings shared by members of the organization (Williams et al., 1993).

\section{1 the statement of problems}

1. Does GCG affect the ERM Implementation?

2. Does Organizational Culture Affect ERM Implication?

3. Does organizational culture moderate the relationship between GCG and ERM Implementation?

\subsubsection{Benefits of Research}

The benefit of this research is to find out whether good corporate governance has an influence on the implementation of ERM, in addition this study also examines the influence of organizational culture whether it influences the relationship of good corporate governance to ERM implementation. 


\subsection{Theoritical Review}

\subsubsection{Good Corporate Governance}

Jensen and Meckling (1976) explain that agent relations are contracts in which one or more people (principals) involve other people (agents) to do several services on their behalf which involve delegating some decision-making authorities to the agent. This theory generally assumes that principals are risk-neutral while agents are risks and attempts to refuse. Agents and principals are assumed to be motivated by their own interests but they often clash (Leslie and Kren 1997). In this case, there is a difference between the interests of shareholders (actors) who expect optimal returns on the capital they have invested and management (agents) who want reasonable compensation for the performance produced. ERM as part of the existing corporate governance mechanism comes to provide certainty over management risks carried out by management that there is certainty about the company's operations in the future, and the agents have the right to be rewarded for their performance in providing certainty in the future.

The phrase "corporate governance" identifies a broad subject both by scope and various stakeholders considered in the process of economic governance and for the scope and diversity of the agency or mechanism of the company responsible for corporate governance (Zattoni, 2004). Corporate governance, with the inherent limitations of each simplification, can be defined as the system in which the company is directed and controlled (Cadbury, 2002), namely as a collection of institutions, rules and relationships between managing bodies and instruments and controls that ensure an effective system of government, efficient and appropriate to safeguard the interests of all corporate stakeholders, as can be understood from the definition provided by OECD (2004).

In recent years, due to various corporate crises, research on government companies has focused on control, a theme that has received more attention than the theme of corporate governance. From the idea that control occurs from outside the company and is carried out mainly by various organizational structures by those who carry out operational activities, the concept has developed in scope to be understood as a process initiated by management within the company (internal control system), which is intended to provide most appropriate to achieve a predetermined goal.

CG studies have relied on a number of competing theories which have arisen mainly from the interdisciplinary nature of CG. Claessens (2006) argues that better CG tends to improve company performance, through more efficient management, better asset allocation, better labor practices or other similar efficiency improvements. The theoretical basis of this research is agency theory. The overall goal of the CG mechanism is to reduce agency problems by aligning the interests of managers and owners and thereby increasing company value (Jensen and Meckling, 1976). Drobetz et al. (2004) argue that agency problems, the foundations of agency theory, tend to have an impact on the company's stock price by influencing the expected cash flows obtained by investors and capital costs. This argument was driven by the belief that low stock prices resulted from investor anticipation of the possibility of transferring company resources.

\subsubsection{Enterprise Risk Management (ERM)}

Risk is something that cannot be avoided by an organization. Risk arises because there are uncertain conditions. According to Hanafi (2009), risks can be grouped into two types, namely pure risk and speculative risk. To be able to manage various risks faced by the company, a risk management tool is needed. The focus of risk management is to understand the risks and take appropriate action on those risks. Efforts to improve the quality of risk management implementation can be done through integrated risk management, namely the implementation of ERM. According to a holistic approach, ERM identifies and assesses various risks, integrates all types of risks, and then coordinates risk management activities for all operating units within an organization. This is contrary to traditional practice, where certain risks are assessed separately by each business unit and they decide for themselves how to handle them (Lin et al., 2012).

According to COSO, ERM is a process that is influenced by management, the board of directors, and other personnel who carry out the determination and incorporation of the overall strategy of the organization, designed to identify potential events that affect the organization, manage risk and also provide adequate trust in achieving organizational goals (Moeller , 2009). The purpose of corporate risk management is to create added value in every organizational activity continuously (Siahaan, 2009). Conceptually, ERM consolidation approaches can add value to the company in several ways. First, by assessing all risks, companies can develop a complete picture of their own risk portfolio. Second, through ERM, companies can prioritize risk factors according to their own risk appetite (Lin et al., 2012). In addition, ERM implementation can help companies make decisions related to activities that must be carried out to carry out business activities with measurable risks (Widjaya and Sugiarti, 2013). Therefore, integrated risk management is needed to make the company better prepared to face risks

\subsubsection{External factors (international and local regulations)}

External factors mainly include more and more international and local regulations. "Cadbury and Turnbull's Report on Corporate Governance" in the United Kingdom [5], King's Report on Corporate Governance in South Africa [6], ERM COSO integrated framework in the United States [7], Risk Management Standards by the European FERMA Risk Management Association [ 8] and the Australian / New Zealand Risk Management Standards [9] are a few examples. Most of these reports include standards and guidelines for companies to implement and 
integrate their risk management processes. Likewise, supranational regulations have also called for a more integrated risk management approach, for example, amendments to the fourth and seventh European directives [10] on annual accounts and joint accounts stipulate that every securities issuing company traded on a regulated market is required to include a statement about corporate governance in its management report.

\subsubsection{Internal factors (company characteristics)}

Most studies of ERM are dedicated to their implementation, costs and benefits (Beasley et al., 2005; Desender, 2007; Nocco and Stulz, 2006; Zhao et al., 2014). However, there are several other studies that investigate the motives behind and the value of the effects of ERM implementation (eg Beasley et al., 2008; Eckles et al., 2014; Hoyt and Liebenberg, 2011; Onder and Ergin, 2012). These studies show the main as follows factors that can motivate companies to adopt ERM. Basically the concept of Enterprise Risk Management - Integrated Framework is to develop an internal control concept that is free of influence and increasingly focuses on aspects of corporate risk management. This concept does not mean to replace the existing internal control framework but rather become a unit. Managers can take advantage of Enterprise Risk Management - Integrated Framework both to fulfill and satisfy internal control needs and to support the risk management process. So it must be anticipated and controlled by managers to how far can an entity be ready to face and accept risks in the effort of creative value.

The underlying premise of enterprise risk management states that each entity is established to create value for stakeholders. Every entity in carrying out operational activities always faces problems of uncertainty. Professional managers are challenged in their competence in the form of the ability to determine how much uncertainty they face can be controlled, so that efforts that lead to increased stakeholder value can be realized. The uncertainties that managers often face can be risks or opportunities that can be obtained through a managerial action that can reduce or increase value creation. Through the implementation of Enterprise Risk Management Integrated Framework, managers are expected to be able to deal effectively with uncertainty issues related to risks and opportunities that can provide potential for increasing value formation capacity.

According to Hanafi (2009), risks can be grouped into two types, namely, among others: pure risk, physical asset risk, legal risk, speculative risk, and market risk, credit risk, liquidity risk, and operational risk and result in losses such as system failure, human error, control and procedures which ultimately disrupt the achievement of objectives. According to COSO, Enterprise Risk Management is a process that is influenced by management, board of directors, and other personnel carried out in determining strategies and covering the organization as a whole, designed to identify events that have the potential to influence the organization, and manage risk, and provide adequate beliefs related to achieving organizational goals.

\subsubsection{Culture}

Cultural meanings can differ depending on a number of interpretations by industry, business or leadership. However, Zabid et al. (2003) state that while many cultural definitions exist, universally seen as holistic, historically determined and socially constructed. Despite the obvious importance of culture, Williams et al. (1993) argue that little attention is given to practical procedures for managing culture. Zabid and Rashid (2003) further show that management style and leadership are important aspects of every company but that leadership and not just management is important for building a strong and positive culture. An important factor that arises from research is the nature of the control system; are they professional? (Hofsted and Hofsted, 1997); what is the source of power and influence? (Trompenaars, 1994); controlling loose and open or tight and pressed? (Hofsted and Hofsted, 1997). Others suggest that other internal stakeholders, employees, are important cultural drivers in an organization (Kotter and Heskett, 1992). Zabid and Rashid (2003) agree with these observations, citing specifically, those employees Attitude and behavior are important factors in the development and identity of an organizational culture. Tseng and Goo (1999) support this view, showing that companies that have employees who are in line with their company's vision and values achieve continuous progress.

Cultural meanings can differ depending on a number of interpretations by industry, business or leadership. However, Zabid et al. (2003) state that while many cultural definitions exist, universally seen as holistic, historically determined and socially constructed. Despite the obvious importance of culture, Williams et al. (1993) argue that little attention is given to practical procedures for managing culture. Zabid and Rashid (2003) further show that management style and leadership are important aspects of every company but that leadership and not just management is important for building a strong and positive culture. An important factor that arises from research is the nature of the control system; are they professional? (Hofsted and Hofsted, 1997); what is the source of power and influence? (Trompenaars, 1994); controlling loose and open or tight and pressed? (Hofsted and Hofsted, 1997). Others suggest that other internal stakeholders, employees, are important cultural drivers in an organization (Kotter and Heskett, 1992).

Zabid and Rashid (2003) agree with these observations, citing specifically, those employees Attitude and behavior are important factors in the development and identity of an organizational culture. Tseng and Goo (1999) support this view, showing that companies that have employees who are in line with their company's vision and values achieve continuous progress. Handy (1993), meanwhile, shows that employee caliber is very important while others show attitudes, competencies and capabilities of the workforce. 


\subsection{Conceptual Framework}

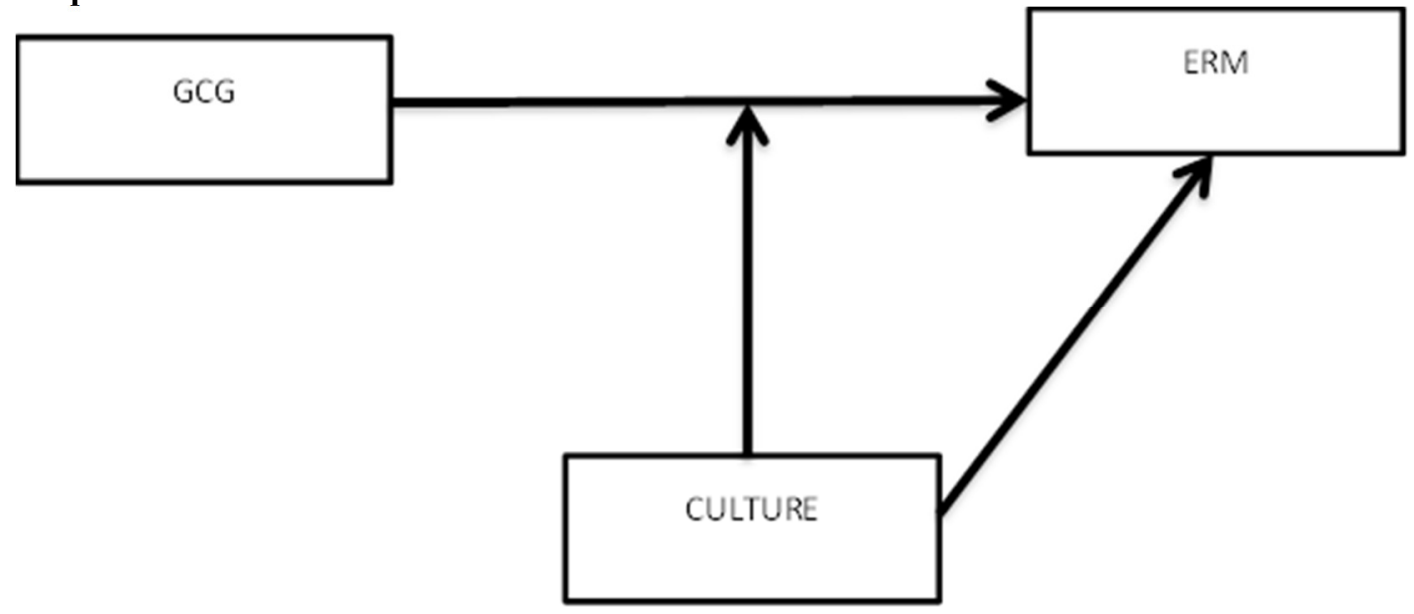

\subsection{Methodology}

The research design used in this study is testing hypotheses by proving whether there is an influence between corporate governance (good corporate governance) on the implementation of enterprise risk management (ERM) and organizational culture (Corporate culture) as a moderating variable between these variables. Indriantoro and Supomo (2009) in Syafri (2016) explain that a hypothesis testing describes phenomena in the form of relationships between variables, which can be correlative, comparative, and causal relationships.

The data and unit of analysis used are perceptions of workers in a company / organization, both manufacturing companies and non-manufacturing companies. The method used in this study is a survey method that is conducting an investigation carried out to obtain the facts of the symptoms and look for information factually.

\subsection{Operational definitions}

\subsubsection{Good Corporate Governance}

Corporate governance, with the inherent limitations of each simplification, can be defined as the system in which the company is directed and controlled (Cadbury, 2002), namely as a collection of institutions, rules and relationships between managing bodies and instruments and controls that ensure an effective system of government, efficient and appropriate to safeguard the interests of all corporate stakeholders, as can be understood from the definition provided by OECD (2004).

\subsubsection{Culture}

Corporate culture is more than just a set of company rules, mission statements and company goals, or even a set of common values; this is a more complex mix of factors that join together to form prevailing organizational culture. Some of these cultural attributes are seen but one key aspect of corporate culture

\subsubsection{Enterprise Risk Management}

According to COSO, ERM is a process that is influenced by management, the board of directors, and other personnel who carry out the determination and incorporation of the overall strategy of the organization, designed to identify potential events that affect the organization, manage risk and also provide adequate trust in achieving organizational goals (Moeller , 2009). The purpose of corporate risk management is to create added value in every organizational activity continuously (Siahaan, 2009).

\subsection{Measurement of Research Variables}

Good corporate governance is measured based on indicators using the Likert scale 1 from strongly disagree to 4 strongly agree. Indicators use indicators from Brocket Rezae Zaebolah (2013).

Enterprise risk management is measured using a Likert scale with indicators from Enterprise risk management from CIMA by collecting perceptions of respondents with a Likert scale where 1 strongly disagrees to 4 strongly agrees.

Culture is measured using a Likert scale with indicators from Brocket Rezae Zaebolah (2013). by collecting the perceptions of the respondents with a Likert scale where 1 strongly disagrees to 4 strongly agrees.

\subsubsection{Data Collection Method}

Data Collection Method used in this research is survey research or through questionnaires, where questionnaires are given to employees who work for companies that have risk management in the company and implement GCG in their company.

\subsubsection{Data Analysis Methods}

The analytical method used in this study is by using multiple regression analysis, namely the model used to assess 
the multivariate relationship between each variable where there are one or more independent variables or there are one or more dependent variables

\section{The Results of Statistical Tests}

\subsubsection{Validity Test}

Validity test is a step of testing carried out on the content of an instrument, with the aim of measuring the accuracy of the instruments used in a study. A valid instrument has high validity. Conversely, instruments that are less valid means having low validity. To find out whether the questionnaire used is valid or not, then the $\mathrm{r}$ obtained ( $\mathrm{r}$ count) is consulted with ( $\mathrm{r}$ table) then the instrument is said to be valid, and if $r$ count $>r$ table then the instrument is said to be valid, and if $r$ count $<\mathrm{r}$ table then instrument said to be invalid. Testing the validity is done by looking at the value of KMO (Kaiser meyer olkin)

1. If $\mathrm{KMO}<\alpha(0.5)$ then the question item is said to be invalid

2. If $\mathrm{KMO}>\alpha(0.5)$ then the question item is said to be valid

\begin{tabular}{|c|c|c|c|}
\hline Variabel & Question & KMO & Result \\
\hline Good Corporate Governance & 5 & 0,589 & Valid \\
\hline ERM & 5 & 0,627 & Valid \\
\hline CULTURE & 5 & 0,608 & Valid \\
\hline
\end{tabular}

Table shows the results of the validity test of the variables launched, namely Good Corporate Governance, Organizational Culture (Culture), and ERM (Corporate Risk Management). From the results obtained, it can be seen from the KMO value of each question item in all variables more than 0.5 so that the variable is valid, then all variables needed are valid and means variables that can be used.

\subsubsection{Reliability Test}

Reliability test is an instrument that is trusted enough to be used as a data collection tool because the instrument is good. A good instrument will not be tendentious or direct the respondent to choose certain answers. Reliable instruments that are reliable will produce reliable data. Reliability testing is done on the variables used by looking at cronbach's alpha as a reliability coefficient. Cronbach's alpha is a positive relationship between questions with each other. The basis of decision-making reliability testing according to Sekaran (2009), is as follows:

- If the Cronbach's Alpha coefficient is $>0.6$ then Cronbach's Alpha is accceptable (construct reliable).

- If the Cronbach's coefficient is Alpha $<0.6$ then Cronbach's Alpha is pooraccceptable (construct unreliable).

\begin{tabular}{|l|l|l|l|}
\hline Variabel & Question & Cronbach's Alpha & Result \\
\hline Good Corporate Governance & 5 & 0,672 & Reliabel \\
\hline ERM & 5 & 0,729 & Reliabel \\
\hline CULTURE & 5 & 0,678 & Reliabel \\
\hline
\end{tabular}

In table, can be seen the results of the reliability test of the variables studied, namely employee performance, job satisfaction, work involvement, and organizational culture obtained Cronbach's Alpha value of more than 0.6 (Cronbach's Alpha $>0.6$ ), it can be concluded that the variables studied consistent (relialbe).

\subsection{Classical Assumption Test}

\subsubsection{Normality test}

This research was conducted with the aim to test that the errors of the regression distributed normally Hypothesis:

Ho: Normal error distribution

Ha: Distribution of errors is not normal

From the results of testing the normality with Kolmogorov Smirnov the results are as follows:

One-Sample Kolmogorov.Smirnov Test

\begin{tabular}{|c|c|c|}
\hline & & $\begin{array}{l}\text { Unstandardiz } \\
\text { ed Residual }\end{array}$ \\
\hline $\mathrm{N}$ & & 51 \\
\hline \multirow[t]{2}{*}{ Normal Parameters ${ }^{a, b}$} & Mean & .0000000 \\
\hline & Std. Deviation & 2.14010204 \\
\hline \multirow[t]{3}{*}{ Most Extreme Differences } & Absolute & .086 \\
\hline & Positive & .084 \\
\hline & Negative & -.086 \\
\hline \multicolumn{2}{|l|}{ Test Statistic } & .086 \\
\hline \multicolumn{2}{|l|}{ Asymp. Sig. (2-tailed) } & $200^{\circ .0}$ \\
\hline \multicolumn{3}{|c|}{ a. Test distribution is Normal. } \\
\hline \multicolumn{3}{|c|}{ b. Calculated from data. } \\
\hline \multicolumn{3}{|c|}{ c. Lilliefors Significance Correction. } \\
\hline
\end{tabular}

The results of calculations based on Table 4.3 show the sig of KS-Z $=0.200>0.05$ so that Ho is accepted and 
the conclusion is a distribution of normal errors. Thus assuming Fulfilled Normality

\subsubsection{Multicollinearity Test}

Multicollinearity test aims to test whether the regression model found a correlation between independent variables.

A good regression model should not have a correlation between independent variables (Ghozali, 2011).

Multicollinearity testing is carried out using VIF (Variant Inflaction Factor) with criteria:

- If VIF $>10$ there is multicollinearity

- If $\mathrm{VIF}<10$ there is no multicollinearity

\begin{tabular}{|c|c|c|c|c|c|c|c|c|}
\hline \multicolumn{9}{|c|}{ Coefficients $^{3}$} \\
\hline \multirow{2}{*}{\multicolumn{2}{|c|}{ Model }} & \multicolumn{2}{|c|}{ Unstandardized Coefficients } & \multirow{2}{*}{$\begin{array}{c}\begin{array}{c}\text { Standardized } \\
\text { Coefficients }\end{array} \\
\text { Beta }\end{array}$} & \multirow[b]{2}{*}{$t$} & \multirow[b]{2}{*}{ Sig. } & \multicolumn{2}{|c|}{ Collinearity Statistics } \\
\hline & & $\mathrm{B}$ & Std. Error & & & & Tolerance & VF \\
\hline \multirow[t]{3}{*}{1} & (Constant) & 10.313 & 2.665 & & 3.870 & .000 & & \\
\hline & GCG & .095 & .172 & .093 & .550 & .585 & .641 & 1.559 \\
\hline & CULTURE & .303 & .190 & .271 & 1.597 & .117 & .641 & 1.559 \\
\hline
\end{tabular}

a. Dependent Variable: ERM

Based on Table From the results of data processing, the results showed that all independent variables in this study did not have multicollinearity, where all VIF values were from variables $<10$. So it can be concluded that the data is free from multicollinearity.

\subsubsection{Autocorrelation Test}

The autocorrelation test aims to test whether in a linear regression model there is a correlation between confounding errors in period t with errors in period t-1 (previously). If there is a correlation, it is called an autocorrelation problem (Ghozali, 2011).

From the results of SPSS processing, the following results are obtained

Model Summary'

\begin{tabular}{|l|l|r|r|r|r|}
\hline Model & $\mathrm{R}$ & R Square & $\begin{array}{c}\text { Adjusted R } \\
\text { Square }\end{array}$ & $\begin{array}{c}\text { Std. Error of } \\
\text { the Estimate }\end{array}$ & $\begin{array}{c}\text { Durbin- } \\
\text { Watson }\end{array}$ \\
\hline 1 & $.335^{\mathrm{a}}$ & .113 & .076 & 2.18423 & 1.790 \\
\hline
\end{tabular}

a. Predictors: (Constant), CULTURE, GCG

b. Dependent Variable: ERM

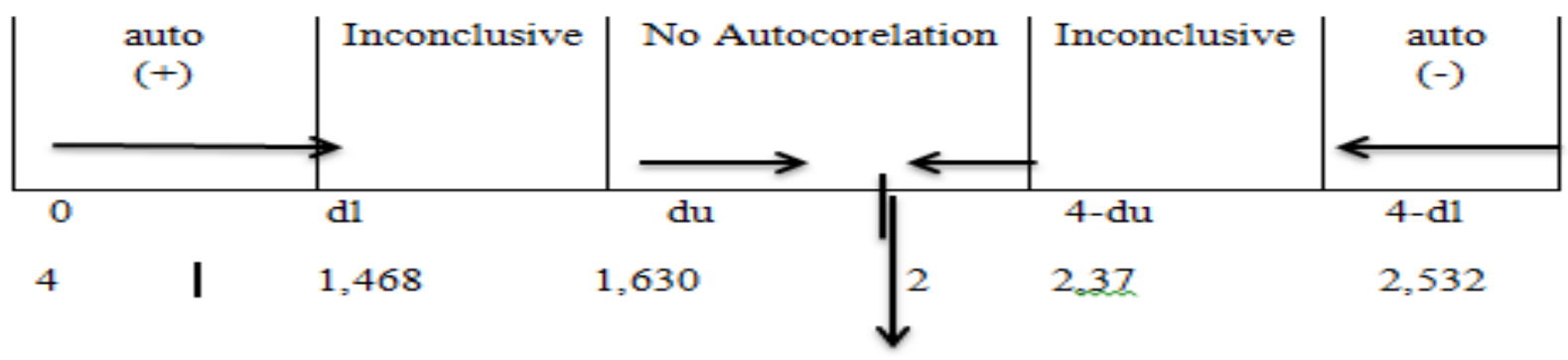

Dy stat $=1,790$

To find out whether there is autocorrelation, it can be seen in the DW table with alpha 5\%, Column $(\mathrm{k}=$ number of independent variables) $=2$ and row (number of samples) $=51$ so that $\mathrm{DL}=1.468$ and $\mathrm{DU}=1.630$.

Based on table shows the results of processing obtained DW value $=1.790$ and is in the area there is no autocorrelation so it can be assumed that the resulting model is free from the problem of autocorrelation.

\subsubsection{Heterocedasticity test}

According to Ghozali (2011), heteroscedasticity test aims to test whether in the regression model variance from residual inequality occurs one observation to another observation. If the residual variance from one observation to another observation remains, then there is no heteroscedasticity so that the regression capital is good. A good regression model is that homoskedasticity or heteroscedasticity does not occur. Heteroscedasticity testing can be done by using the Gletsjer Test, which is the regression between absolute residuals and each independent variable. Hypothesis

Ho: There is no heteroscedasticity

Ha: There is heteroscedasticity

The decision making criteria are as follows:

- If sig is $t<0.05$, there is heterocedasticity

- If sig is $t>0.05$, there is no heterocedasticity 
Coefficients $^{\mathrm{a}}$

\begin{tabular}{|c|c|c|c|c|c|c|}
\hline \multirow[b]{2}{*}{ Mode } & & \multicolumn{2}{|c|}{ Unstandardized Coefficients } & \multirow{2}{*}{$\begin{array}{c}\begin{array}{c}\text { Standardized } \\
\text { Coefficients }\end{array} \\
\text { Beta } \\
\end{array}$} & \multirow[b]{2}{*}{$t$} & \multirow[b]{2}{*}{ Sig. } \\
\hline & & $B$ & Std. Error & & & \\
\hline \multirow[t]{3}{*}{1} & (Constant) & 3.147 & 1.701 & & 1.850 & .070 \\
\hline & GCG & -.038 & .072 & -.077 & -.535 & .595 \\
\hline & CULTURE & -.049 & .077 & -.091 & -.635 & .528 \\
\hline
\end{tabular}

a. Dependent Variable: ABSRESID

Based on the picture Table from the results of data processing, it was found that all independent variables had a significance of $t>0.05$. So it can be concluded that there is no heterocedasticity in the research variable.

\subsubsection{Model Test (Coefficient of Determination - R2)}

Model Summary

\begin{tabular}{|l|c|r|r|r|r|}
\hline Model & $\mathrm{R}$ & $\mathrm{R}$ Square & $\begin{array}{c}\text { Adjusted R } \\
\text { Square }\end{array}$ & $\begin{array}{c}\text { Std. Error of } \\
\text { the Estimate }\end{array}$ & $\begin{array}{c}\text { Durbin- } \\
\text { Watson }\end{array}$ \\
\hline 1 & $.335^{\mathrm{a}}$ & .113 & .076 & 2.18423 & 1.790 \\
\hline
\end{tabular}
a. Predictors: (Constant), CULTURE, GCG

b. Dependent Variable: ERM

Based on table ., showing the magnitude of the correlation $(\mathrm{R})$ is 0.076 . This means that there is a fairly strong relationship from the independent variable (GCG) to the dependent variable (ERM). The amount of $\mathrm{R}^{2}$ is 0.076 or $7,6 \%$, which means that the independent variable can have an effect of $11.3 \%$ on the dependent variable, while the rest $(100 \%-7,6 \%=92.4 \%)$ is a variation of other independent variables that affect the quality of Sustainability Report but not included in the model

\section{3t-Test \& F-Test}

\subsubsection{Test $F$}

The F test is used to test whether all the independent variables have a significant influence on the dependent variable tested at a significant level of 0.05 . In this F Test, it is tested whether there is an effect of Good Corporate Governance and Culture on the implementation of Enterprise Risk Management. The basic decision making for this hypothesis is:

- If sig is from $\mathrm{F}>0.05$, then Ho is accepted and $\mathrm{Ha}$ is rejected.

- If sig is from $\mathrm{F}<0.05$, then Ho is rejected and Ha is accepted.

The null hypothesis statement (Ho) and alternative hypothesis (Ha) are as follows:

\section{ANOVA ${ }^{\mathrm{a}}$}

\begin{tabular}{|rl|r|r|r|r|r|}
\hline \multicolumn{1}{|c|}{} & \multicolumn{1}{c|}{$\begin{array}{c}\text { Sum of } \\
\text { Squares }\end{array}$} & df & Mean Square & F & Sig. \\
\hline 1 & Regression & 38.175 & 2 & 19.088 & 4.167 & $.021^{\text {b }}$ \\
& Residual & 219.864 & 48 & 4.581 & & \\
& Total & 258.039 & 50 & & & \\
\hline
\end{tabular}
a. Dependent Variable: ERM
b. Predictors: (Constant), CULTURE, GCG

Based on table, the results of statistical processing show a significance value of $0.02<0.05$, meaning that Hol is rejected and Hal is accepted, so it can be concluded that there is an effect of GCG and Culture simultaneously / affecting the dependent variable ERM ..

\subsubsection{Significant Test $t(t$ Test)}

The $t$ test basically aims to find out individually the influence of one independent variable on the dependent variable. If the significant value generated by the $\mathrm{t}$ test is $\mathrm{P}<0.05$, it can be concluded that the independent variable has a significant effect on the dependent variable. 
Coefficients $^{\mathrm{a}}$

\begin{tabular}{|c|c|c|c|c|c|c|c|c|}
\hline \multirow{2}{*}{\multicolumn{2}{|c|}{ Model }} & \multicolumn{2}{|c|}{ Unstandardized Coefficients } & \multirow{2}{*}{$\begin{array}{c}\begin{array}{c}\text { Standardized } \\
\text { Coefficients }\end{array} \\
\text { Beta }\end{array}$} & \multirow[b]{2}{*}{$t$} & \multirow[b]{2}{*}{ Sig. } & \multicolumn{2}{|c|}{ Collinearity Statistics } \\
\hline & & $B$ & Std. Error & & & & Tolerance & VIF \\
\hline \multirow[t]{3}{*}{1} & (Constant) & 8.233 & 3.010 & & 2.735 & .009 & & \\
\hline & GCG & .272 & .127 & .286 & 2.147 & .037 & .998 & 1.002 \\
\hline & CULTURE & .248 & 136 & .243 & 1.825 & .074 & .998 & 1.002 \\
\hline
\end{tabular}

a. Dependent Variable: ERM

\subsection{Discussion}

\subsubsection{The Effect of GCG on ERM Implementation}

Based on the results of the data show that sig 0.037 with Beta 0.272 , which illustrates that there is a positive influence between good corporate governance on ERM Implementation. So that the H1 hypothesis is accepted 4.4.2Culture Influence on ERM Implementation

Based on the results of the data show that sig 0.074 with Beta 0.248 , which illustrates that there is no influence between Culture on ERM. So the H2 hypothesis is rejected

\subsubsection{RESULTS OF THE MODERATION TEST}

Regresion Without Moderating Variable

Model Summary ${ }^{\mathrm{b}}$

\begin{tabular}{|l|c|r|r|r|r|}
\hline Model & R & R Square & $\begin{array}{c}\text { Adjusted R } \\
\text { Square }\end{array}$ & $\begin{array}{c}\text { Std. Error of } \\
\text { the Estimate }\end{array}$ & $\begin{array}{c}\text { Durbin- } \\
\text { Watson }\end{array}$ \\
\hline 1 & $.335^{\mathbf{a}}$ & .113 & .076 & 2.18423 & 1.790 \\
\hline
\end{tabular}

a. Predictors: (Constant), CULTURE, GCG

b. Dependent Variable: ERM

Regresion With Moderating Variable

Model Summary ${ }^{b}$

\begin{tabular}{|l|c|r|r|r|r|}
\hline Model & $R$ & R Square & $\begin{array}{c}\text { Adjusted R } \\
\text { Square }\end{array}$ & $\begin{array}{c}\text { Std. Error of } \\
\text { the Estimate }\end{array}$ & $\begin{array}{c}\text { Durbin- } \\
\text { Watson }\end{array}$ \\
\hline 1 & $.487^{\mathrm{a}}$ & .238 & .189 & 2.04599 & 1.561 \\
\hline
\end{tabular}

a. Predictors: (Constant), CULTURE, GCG, XZ

b. Dependent Variable: ERM

Based on the results of the regression performed. R2 is obtained in the First Regression of 0.113 (11.3\%), while after there is a second regression equation table 4.15, that is after the moderating variable, ie organizational culture is carried out, R2 in the second regression increases to $23.8 \%$. With this, it can be concluded that the presence of organizational culture (Moderating Variables) can strengthen the relationship between the independent variables (Good Corporate Governance) on the dependent variable (Enterprise Risk Management). Thus the Organizational Culture Strengthens the Effect of Corporate Governance on ERM Implementation. Hypothesis (H3) is accepted.

\section{CONCLUSION}

Based on the results of the analysis that have been tested statistically it can be concluded as follows: First, Of the two independent variables tested in this study, not all variables have a significant influence on ERM implementation. Corporate governance has a significant positive effect on ERM implementation. Second, There is a variable that has no effect on ERM, which is a culture where there is no significant influence between culture on ERM. Third, Moderation variables in this study, namely organizational culture proved to strengthen the relationship between the independent variable (good corporate governance) to the dependent variable (ERM Implementation).

This study has several limitations, namely: First, This research is still classified as new research, so researchers experience limitations in determining the theories used. Second, the sample in this study is very limited, with the number of respondents as many as 51 respondents. Third, the unwillingness of some respondents to be used as research samples. Fourth, the criteria for the sample are less specific.

The results of the study have managerial implications that can provide input to company managers that the 
company's organizational culture does not always affect something within the company, one of which is if the company wants to implement ERM within the company. Companies must create a good organizational culture in carrying out their business, by training employees so that they have good abilities and implementing systems of reward and punishment in management.

Suggestions that can be given for further research include: 1 . Further research is recommended to consider conducting similar research in other companies, and using a larger number of research samples. 2. Further research can examine other variables that can be tested.

\section{References}

Cynthia Afriani Utama, Sidharta Utama, Fitriany Amarullah, (2017) "Corporate governance and ownership structure: Indonesia evidence", Corporate Governance: The International Journal of Business in Society, Vol. 17 Issue: 2 , pp.165-191

Citrawati, Fauzi, Pengaruh Corporate Governance Dan Konsentrasi Kepemilikan Pada Pengungkapan Enterprise Risk Management (ERM), 2011

Iswajuni Iswajuni, Arina Manasikana, Soegeng Soetedjo, (2018) "The effect of enterprise risk management (ERM) on firm value in manufacturing companies listed on Indonesian Stock Exchange year 2010-2013", Asian Journal of Accounting Research, Vol. 3 Issue: 2, pp.224-235,

Justine Simpson, John Taylor, (2013), Corporate Governance, Ethics, and CSR, London.

Majid Jamal Khan, Dildar Hussain, Waqar Mehmood, (2016) "Why do firms adopt enterprise risk management (ERM)? Empirical evidence from France", Management Decision, Vol. 54 Issue: 8, pp.1886-1907

Michail Nerantzidis, Anastasios Tsamis, (2017) "Going back to go forward: on studying the determinants of corporate governance disclosure", Corporate Governance: The International Journal of Business in Society, Vol. 17 Issue: 3, pp.365-402,

Pedoman Umum Good Corporate Governance Indonesia, 2006, Dikeluarkan oleh Komite Nasional Kebijakan Governance

Rubino Michele, Vitolla Filippo, Corporate Governance and the information system : how a framework for IT governance supports ERM, 2014

R. L. Kimbrough, Deloitte \& Touche LLP P. J. Componation, The University of Alabama in Huntsville, The Relationship Between Organizational Culture and Enterprise Risk management 